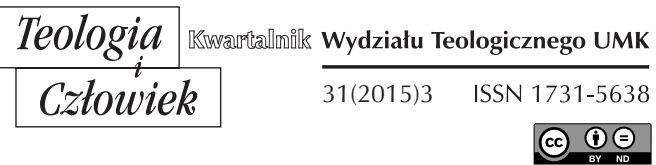

JOSEPH ELLUL, O.P.*

VALLETTA-ROME

\title{
THE CONCEPT AND THE EXPERIENCE OF SUFFERING IN THE ISLAMIC TRADITION
}

DOI: http://dx.doi.org/10.12775/TiCz.2015.041

The human experience of suffering can be considered in its various manifestations: physical, psychological, moral and spiritual. Sometimes these are interconnected, and it is difficult to distinguish among them. This paper is intended as an overview of the concept and experience of suffering in the Islamic tradition as portrayed in the context of the Qur'ân and of the life of Muhammad, its exaltation in the cause of religion within the $\breve{S}_{1} \mathbf{1} \overline{1}$ community, as well as the development of its understanding in theological, philosophical and mystical circles.

\section{ISLAM AS THE NATURAL RELIGION OF HUMANITY}

In order to understand better the way Islam approaches the theme of human suffering it is necessary to begin with a few reflections on the

* Rev. Dr Joseph Ellul OP is a lecturer in the Faculty of Arts and the Faculty of Theology as the University of Malta, lecturer in theology at the Pontifical University of St. Thomas Aquinas and the Pontifical Institute of Arabic and Islamic Studies in Rome, member of the Committee of Committee for Relations with Muslims of the Council of European Bishops' Conferences, and consultor to the Pontifical Council for Interreligious Dialogue. 
relationship between God and humanity as described in the Qur'ân. For the Muslim God is the One of whose presence the Qur'ân calls humanity to be mindful. The Qur'ân addresses itself to humanity and humanity is called upon to respond. A common theme running throughout the Qur'ân is that all the different phases of human life serve as a testing ground. Life and death, together with the constant warning of severe punishment meted out to the unrighteous, fall under the omnipotent will of God and are meant to put humanity to the test. Paradise is Man's final reward, which is always portrayed as the level of nature within which eternal bliss is situated. God will reward the elect with the best that is to be found on earth. This concept is graphically portrayed not only in the text of the Qur'ân itself but also in two of the greatest masterpieces of Islamic art and architecture, the Alhambra in Granada and the Taj Mahal in Agra.

The first creation and eternal life are two parallel realities; the latter is portrayed as a resumption of creation:

It is to Him that you shall all return - a true promise from God. It was he who created [you] in the first place, and He will do so again, so that He may justly reward those who believe and do good deeds. But the disbelievers will have a drink of scalding water, and agonizing torment, because they persistently disbelieved. (Q. 10:4) ${ }^{1}$

Life consists of a series of dynamic processes beginning with conception and ending with death. In all these stages the omnipotence of God is continuously stressed by the Qur'ân, in order to underline the message that the Giver of life is also its restorer on the Day of Resurrection.

Creation constantly teaches that God is All-Powerful (Qadīr) ${ }^{2}$. This divine attribute is intimately linked with divine oneness (tawhīd) . Since God is All-Powerful, then no creature can claim the power to create (halaqa). Whatever good or evil God may will for his creatures, it reaches them without their having any power to halt or change it:

${ }^{1}$ Unless otherwise indicated all citations from the Qur'ân in this article are taken from The Qur'an: English Translation and Parallel Arabic Text, Translated with an Introduction and Notes by M. A. S. Abdel Haleem, Oxford 2010.

2 See Q. 35:1.44. 
If God touches you [Prophet] with affliction, no one can remove it except $\mathrm{Him}$, and if He touches you with good, He has power over all things: $\mathrm{He}$ is the Supreme Master over His creatures, the All Wise, the All Aware. (Q. 6:17-18)

\section{THE EXPERIENCE OF SUFFERING IN THE LIFE OF THE EARLY MUSLIM COMMUNITY}

God is not unaware of human suffering, especially the suffering of those who are faithful to him. The Qur' ân provides evidence of divine providence in the face of adversity, when it recalls Muhammad's childhood and youth:

By the morning brightness and by the night when it grows still, your Lord has not forsaken you [Prophet], nor does he hate you, and the future will be better for you than the past; your Lord is sure to give you [so much] that you will be well pleased. Did He not find you an orphan and shelter you, find you lost and guided you, find you in need and satisfy your need? (Q. 93:1-8)

The Prophet's poverty derived from his condition as an orphan. According to the earliest Muslim chroniclers Muhammad never knew his father ${ }^{\mathrm{c}}$ Abd Allāh, who was said to have died on a journey, while his wife Amina was with child. She in turn died when her son was six years old; Muhammad's grandfather passed away two years later. Thus, at the age of eight, he was taken in by his uncle Abū Țālib, who brought him up and then bravely protected him from all those who were set against him. As for his being lost, it is a matter of placing Muhammad's recollection of things past within the context of the bounty and goodness of God. It also enhances his prestige as one who is privileged by a unique relationship with the divine. God's favour provides the Prophet with a lesson to act likewise with the socially weak and the marginalized whom he encounters on a daily basis:

So do not be harsh with the orphan and do not chide the one who asks for help; talk about the blessings of your Lord. (Q. 93:9-11) ${ }^{3}$

3 These commands are in line with the Old Testament injunctions regarding 
The narrative involves a progression. Starting with a particular fact, namely Muhammad's past, the text then points at once to the attitude of God towards his trials and tribulations. Finally, a conclusion is drawn, with a view either to social action or to the praise of God. This modus procedendi is found inversely in the Bible, especially in those Old Testament passages where God first enjoins his people to care for the weak and the marginalized after which he reminds them of their past as slaves and foreigners in Egypt ${ }^{4}$. The question of suffering in the Qurân gradually develops into a series of recollections detailing the tribulations which Muhammad and the Muslim community underwent in the course of twenty-two years, beginning with his claim to prophethood and culminating in his death in 632. In between these two events lies one reference after another to persecution, mental anguish, and renewed faith in God, who finally avenges those who struggle ( $\breve{g} i h \bar{a} d)$ against huge odds in his cause (fí sabìl Illäh) and consequently suffer. The stories of the prophets in the Qurân are set within this common autobiographical framework: God chooses a man from the midst of his impious polytheistic people and sends him to 'recall' them to the original monotheism professed by humanity at the dawn of time; the people refuse to listen to the prophet, they persecute him and try to kill him; but God intervenes to save his prophet and to punish the faithless and wicked people. It is therefore possible to recognize in the outline of Muhammad's personal experience images of past prophetic figures, who are thus seen as having anticipated him and supported his cause $e^{5}$. The same line of thought would apply to the early Muslim community, which had to bear derision, ostracism, humiliation,

behaviour towards widows, orphans and foreigners. Cf. Lv.19:9-10; Dt. 24:19. The same notion is to be found in the New Testament; see Mt. 25:31-46. The fundamental difference lies in the fact that, whereas in the Old Testament and in the Qurân such conduct is in obedience to the divine command, in the New Testament Jesus himself becomes the criterion of conduct towards the marginalized: "Truly, I say to you, as you did it to one of the least of these my brethren, you did it to me" (Mt. 25:40).

${ }^{4}$ See Ex. 22:21; 23:9.

${ }^{5}$ See Q. 22:42-48. For the story of Noah see Q. 7:59-64; for the story of Hûd and the People of 'Âd see Q. 7:65-72; for the story of Sâlih and the People of Tamûd see Q. 7:73-84; for the story of Šu'ayb and the People of Madian see Q. 7:88-92; for the story of Abraham see Q. 21:51-70; for the story of Lot see Q. 7:80-84; for the story of Moses see Q. 2:49-61. The accounts of all these prophets are also to be found in Q. 11:25-98. 
persecution and later even the death of loved ones, relatives, and faithful Companions on the battlefield. The feeling of powerlessness could drive one to despair. Here the Qur'ân counsels patience and self-control:

So [Prophet] be steadfast: your steadfastness comes only from God. Do not grieve over them; do not be distressed by their scheming, for God is with those who are mindful of Him and who do good. (Q. 16:127-128) ${ }^{6}$

The Qurân refers to instances of apostasy and to the Prophet's grief at these acts of betrayal. Its response is that this is not a personal rejection of Muhammad; it is, rather, a far more heinous crime: the rejection of God and of his message. Even the prophets who preceded him suffered the same agony:

We know well that what they say grieves you [Prophet]. It is not you they disbelieve: the evildoers reject God's revelations. Other Messengers were disbelieved before you, and they bore their rejection and persecution steadfastly until Our aid arrived - no one can alter God's promises. (Q. 6:33-34) ${ }^{7}$

Faced with such obstinate hard-heartedness the Prophet and his followers can only have recourse to the omnipotence of God. Conscious of his own inability to convince, Muhammad calls upon God, who alone can open hearts (šarh al-șadr) to Islam ${ }^{8}$ and bring about belief or unbelief.

Here again the Qur'ân vindicates the Muslim community by referring to past events, in which Christian and Jewish communities were persecuted by evil people but emerged victorious through divine intervention:

Those who have been attacked are permitted to take up arms because they have been wronged - God has the power to help them - those who have been driven unjustly from their homes only for saying, 'Our Lord is God.' If God did not repel some people by means of others, many monasteries, churches, synagogues and mosques, where God's name is invoked, would have been destroyed. God is sure to help His cause - God is strong and mighty. (Q. 22:39-40)

${ }^{6}$ See also Q. 30:52; 6:114.116; 7:158; 17:72-73.

7 See also Q. 10:65; 31:23. The notion that the rejection of the prophet is implicitly a rejection of God who sent him is a recurring theme in the Biblical tradition; see, for example, 1 Sam. 8:7; Jer. 7:1-15; 20:1-6.

${ }^{8}$ See Q. 6:125; 39:22; 94:1. 
The Qurân's discussion of death is associated with the concept of divine justice. God makes no exceptions ${ }^{9}$. After death the human soul encounters the souls of all the departed, those of the believers (alMu'minūn, who are now enjoying eternal bliss) as well as those of the unbelievers (al-Kuffär, who are now suffering eternal anguish). According to Muslim tradition, a pair of angels, Nakìr (The Denier) and Munkar (the Denied) interrogate the soul in the tomb (fitnat al-qabr) regarding its fidelity to God and his precepts during its earthly life as well as the works the person had performed during his/her lifetime. The unfaithful soul will be punished severely. The soul then returns to the tomb. God bestows death twice and twice does he bestow life to the human being. The first time is when the child is still hidden in its mother's womb and then is born; the second time is when the human being dies and then rises again after judgement is passed. It appears, however that the second death is decidedly more severe for the unbelievers:

But those who disbelieved will be told, 'When you were called to the faith and rejected it, God's disgust with you was even greater than the self-disgust you feel [today].' They will say, 'Our Lord, twice You have caused us to be lifeless and twice You have brought us to life. Now we recognize our sins. Is there a way out?' (Q. 40:10-11)

As soon as the soul of the unbeliever is reunited to the body he/she will experience the torments of fire night and day till the Day of Resurrection ${ }^{10}$. As for the hypocrite (al-munäfiq) who is inconstant in his/her fidelity, God knows well what lies hidden within one's heart. Consequently, the suffering of the hypocrites will be doubly severe ${ }^{11}$. The descriptions in the Qur'ân of punishment for unbelief are quite gory and laid out in graphic detail. The Arabic term used for Hell, namely al-Ğahannam, refers to a place that is covered from God's sight. As in the case of New Testament depictions of $\mathrm{Hell}^{12}$, it is portrayed as a place of unquenchable

\footnotetext{
${ }^{9}$ See Q. 3:185; 50:19.

10 See Q. 40:46-50.

11 See Q. 9:101.

12 See Mt. 25:41; Jude 7; Ap. 20:10.
} 
fire ${ }^{13}$. Those who are placed in Hell fall into the hands of merciless angels and are used to kindle its flames:

Believers guard yourselves and your families against a Fire whose fuel is people and stones, over which stand angels stern and strong; angels who never disobey God's commands to them, but do as they are ordered: 'You who disbelieve, make no excuses today: you are only being repaid for what you used to do. (Q. 66:6-7) $)^{14}$

They will eat from the fruit of the tree of Zaqqūm that sheds small leaves which have a bitter taste. They will fill their bellies with them, but they will remain forever hungry. This food will turn into boiling tar in their stomachs. They will also be given boiling water to drink:

Say [Prophet], 'The earliest and latest generations will be gathered on a predetermined Day and you who have gone astray and denied the truth will eat from the bitter tree of Zaqqum, filling your bellies with it, and drinking scalding water, lapping it like thirsty camels.' This will be their welcome on the Day of Judgement. (Q. 56:49-56) ${ }^{15}$

At times boiling water will be poured upon their heads and scald their faces. Other torments await the unbelievers. Their skin will be burned till it falls off; and then they are given new skins so that it can be burned away once more, thereby causing an unending cycle of excruciating pain:

We shall send those who reject Our revelations to the Fire. When their skins have been burned away, we shall replace them with new ones so that they may continue to feel the pain: God is mighty and wise. (Q. 4:56)

Their garments will be made of pitch and their faces covered with fire in order to melt their bodies ${ }^{16}$. At this point remorse is to no

13 The source of the image of Hell as a place of unquenchable fire goes back at least as far as Is. 66:24 (the very last verse): "And they shall go forth and look on the dead bodies of the men that have rebelled against me; for their worm shall not die, their fire shall not be quenched, and they shall be an abhorrence to all flesh". See also Mk. 9:48.

14 See also Q. 74:26-29; 9:81.

15 See also Q. 37:63-67; 17:60.

${ }^{16}$ See Q. 14:50. 
avail, because their suffering becomes an unending cycle of hideous torture ${ }^{17}$.

\section{EVIL, SUFFERING, AND PUNISHMENT IN THEOLOGICAL THOUGHT AND IN POPULAR BELIEF}

Confronting the problem of human suffering took on an added urgency with the spread of Islam and the encounters of Muslims with non-Muslim (especially Christian) communities, who had developed and refined Hellenistic thought and thus sought to address the problem of human suffering and link it directly to the existence of evil. Schools of Islamic theology began to develop philosophical arguments in order to respond to questions concerning the presence of evil. Just like any other religion Islam had to come to grips with questions regarding the suffering of innocent people, the prophets (al-Anbiyä) and the righteous (alSälihinn). This question is a constant theme of Muslim theology (kalām). The Mu'tazila School considered that God does only good, and therefore, if he lays suffering on the innocent, this is because it is for their benefit, even if one cannot as yet grasp its significance. Suffering is considered more as a beneficial trial for the believer, who will be rewarded in some mysterious way. The Ašariyya School, on the other hand, adopted a more arbitrary stand in declaring that God is free to do whatever he wishes and may inflict pain and suffering on whomever he wishes, without being obliged to provide a motive, and even without the need to bestow any eventual compensation or reward. That view notwithstanding, the distinguished Ašarī theologian Abū Hāamid al-Ġazāli (1058-1111) gave a much more nuanced approach to the problem:

The merciful one certainly wants good for the one who receives mercy. Yet there is no evil in existence which does not contain some good within it, and were that evil to be eliminated, the good within it would be nullified, and the final result would be an evil worse than the evil containing the good...

17 See Q. 10:54. 
But if He intended good for the good itself, yet intended evil not for itself but because there is some good within it; then good is accomplished essentially but evil is accomplished accidentally, and each according to divine decree ${ }^{18}$.

Here again, one cannot mention human suffering without mentioning death and what follows thereafter. Popular belief, stemming from a number of early Muslim creedal statements, is rich with accounts concerning death. Apart from the standard profession of the faith, the šahada, other formulae appeared during the first three centuries of Islam, all of them forged largely for the purpose of polemics with heterodox sects. All the major formulae include references to death, and particularly about the so-called "punishment of the grave" together with the interrogation of the deceased by angels as to the good and evil committed during life. These two features appear to have originated in the sayings (hadit $\underline{t}$ ) of the Prophet and imply that after death the deceased retain their faculties of perception ${ }^{19}$. Unbelievers will surely suffer there and perhaps even believers who have sinned, although the latter may count on the intercession of the Prophet who, however, acts only by God's leave ${ }^{20}$. All will be sub-

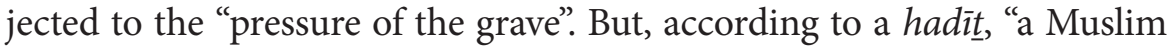
who passes away on a Friday or on a Friday night will be saved from the punishment of the tomb"21. Neither the angels' interrogation nor the pressure and punishment of the grave are mentioned explicitly in the Qurân. They are traditional elements which gradually became integrated into the religious life of Muslims until they reached the status of quasi articles of faith ${ }^{22}$.

18 Al-Gazâlî, al-Maqsad al-asnâ fî sharh asmầ Allâh al-husnâ (The Ninety-Nine Beautiful names of God), translated with notes by David B. Burrell and Nazih Daher, Cambridge 1992, p. 55f.

19 John Renard, "Islamic Perspectives on Death", Studies in Formative Spirituality, vol. II Number 2, May 1981, p. 193.

20 See Q. 2:255.

${ }^{21}$ Al-Tirmidīi Saḥ̄ḥ, Ğanā'iz, 72; Aḥmad b. Ḥanbal, Musnad, 6:169, 176, 220. See Renard, op. cit., p. 193.

${ }^{22}$ J. Renard, op. cit., p. 193. See also A.J. Wensinck, The Muslim Creed, New York 1965, pp. 117ff. 163ff. 221ff. 


\section{"REDEMPTIVE" SUFFERING AND MARTYRDOM IN Šİ'̄ ISLAM}

Suffering has played an immense role in the life experience of the Muslim Sìi ì community. The assassination of 'Alī, cousin and son-in-law of the Prophet and the slaying of his son Husayn at the Battle of Karbala in 680 have been a source of inspiration throughout centuries of ostracism and persecution that has led $\check{S}_{i}^{-}$is to develop their own interpretation of the Qur'ân and, consequently, their own theological thought. They are two events which are considered as an unavoidable sacrifice that ultimately works for the redemption of humanity. They are expressed pre-eminently in Šìì Qurânic exegesis, as the distinguished scholar Mạ̣mūd Ayoub has poignantly evoked:

For Muslims, the Qurân is a guide through this life and into the next. Thus, the science of understanding the Qurân (tafsir) may be regarded as the child of piety, of fear of God's punishment for ignorance and hence disobedience, and of hope in God's mercy and reward for understanding and hence obedience. For the Shīi community, the Qurân is all that and more. Tafsir is also the child of frustration and disappointment, of hope and exultation. It is the child of the ethos of martyrdom and eschatology. Through tafsir, the link between the faithful and their spiritual guides, the Imāms, is established. Tafsìr is the humanization of the divine word and the divinization of the human spirit ${ }^{23}$.

One famous annual but not strictly official observance occurs in still traditional regions of Twelver Šìi Muslims. During the first ten days of the first lunar month, Muharram, $\check{S}_{i}$ i ites commemorate the martyrdom of Husayn at Karbala with poems and stories of mourning and lamentation. Some worshipers even perform severe acts of physical penance, such as self-flagellation and mutilation, in a show of sympathy. Both Karbala and Nağaf (which houses the remains of 'Alī) are venues for annual pilgrimages by thousands of Šìi devotees. The commemoration itself reaches its climax with the ta'ziya, a play depicting the sufferings of pre-Islamic prophets reaching its climax with the re-enactment of Husayn's martyrdom.

${ }^{23}$ Mahmoud Ayoub, “The Speaking Qurân and the Silent Qurân: A Study of the Principles and Development of Imāmī Shīī tafsīr", in A. Rippin (ed.), Approaches to the History of the Interpretation of the Qurân, Clarendon Press, Oxford 1988, p. 177. 
In this way, Husayn stands in a long line of holy persons who have experienced rejection, persecution and, ultimately, death at the hands of the unbelievers. While commenting on the text of the play, John Renard stresses that it underlines in many ways, "their suffering redeems all who are well disposed, and in the end their forgiveness softens the hardest of hearts. In Husayn's case, the martyr intercedes even for Šimr, his murderer and agent of the tyrannical Umayyad caliph Yazid"24.

The figure of Joseph ${ }^{25}$ figures prominently in the literature and lore associated with the redemptive suffering of Prophets and Friends of God (the mystics), a theme of great importance in $\check{S}_{1}^{-} \mathrm{i}$ devotional tradition. All God's prophets suffer at the hands of unbelieving people, and their endurance is a mark of their friendship with God. Joseph's story is especially moving because, just as with the case of Abraham, ${ }^{26}$ the opposition comes from his own family ${ }^{27}$. Here Joseph becomes a model of patience and perseverance in the face of adversity.

In the above-mentioned ta'ziya plays commemorating the martyrdom of Husayn, the tribulations of Joseph and his father, Jacob, become the hallmark of redemptive suffering for Šìi $\check{i}^{-}$Muslims. The scenes that portray the story of Joseph are in general an embellishment of the Qurânic account. They heighten the emotional effect by emphasizing the torment that the prophet and his father were forced to endure. Jacob undergoes the trauma of seeing the bloodstained coat of his son. As he looks into the future, he wonders how much greater the pain of the mother of Husayn (Fātima) will be, when she sees the shirt of her son who has been so brutally slain. He prays that a thousand like himself and Joseph might be Husayn's ransom and then beseeches Gabriel to demonstrate to him the scene at Karbala still so many centuries in the future ${ }^{28}$.

Classic hagiographical sources in Šìi Islam recount stories of two kinds of religious figures, namely the prophets, beginning with Muhammad's life story (Sìra), and other holy persons, whom the Islamic

${ }^{24}$ J. Renard, Seven Doors to Islam: Spirituality and the Religious Life of Muslims, University of California Press, Berkeley (CA) 1996, p. 63.

25 The story of Joseph is recounted in the Qurân. See Q. 12.

${ }^{26}$ See Q. 21:51-72.

${ }^{27}$ J. Renard, op. cit., p. 262. See Q. 12:7-20.

${ }^{28}$ J. Renard, op. cit., p. 262. 
tradition calls Friends of God. Both have served special purposes over the centuries since the age of the last prophet. Holy persons have functioned as intercessors and mediators, and in popular spirituality they have helped people to identify and gain access to the wellsprings of God's bounty, blessing and power. Muslims acknowledge that God manifests his power and presence through chosen persons, who also serve as inspired examples. In this way, belief in the redemptive quality of the suffering and death of certain members of the Prophet's family is intimately bound with the notion of intercession.

\section{CAUSES OF SUFFERING AND ITS REMEDIES IN PHILOSOPHICAL DISCOURSE}

The philosophical aspect of the question of suffering has been discussed among Islamic philosophers within the framework of their treatises on ethics. The two principal authors who dealt with this issue were Abū Yūsuf Ya'qūb b. Isḥaq al-Kindì (c. 801-866) and Abū Bakr alRāzī (864-925 or 932).

\section{a. Al-Kindī}

One of the longest treatises of al-Kindī (c. 801-866) is The Art of Dispelling Sorrows. In this work he reasons about the phenomenon of sorrow from the perspective of things that fall within the purview of common human observation. He calls upon that experience to set forth his teaching about the nature of sorrow and applies it also with reference to his advice on adopting an ascetic lifestyle. Al-Kindī envisages the goal of human life as that of gaining security from the misfortunes of sorrow in order to reach "the most virtuous homeland of the abode of permanence and the dwelling place of the righteous" 29 . Fundamental to the exposition provided here is al-Kindī's exhortation to pay less attention to the things cherished by one's fellow human beings

${ }_{29}$ Al-Kindi, On the means of dispelling sorrows, 33, in Classical Arabic Philosophy: An Anthology of Sources, translated with Introduction, Notes, and Glossary by Jon McGinnis \& David C. Reisman, Indianapolis/Cambridge [MA] 2007, p. 35. 
and to concentrate on what is most important for a human life directed toward something beyond sensual pleasure. Al-Kindī begins by explaining what sorrow is, given that "the cure will not be found for any pain whose causes are not known" ${ }^{30}$ He then proceeds to furnish a description of pain by stating that it is actually "a psychological pain that appears owing to the loss of loved things or the failure to obtain the things one desires" 31 . Since it is clear that no one can acquire all the things he seeks nor avoid losing any of the things he loves, the only way to avoid sorrow is to be free of these attachments. In other words, "we should not be sad about what passes us by and the loss of cherished things, and through proper habit, we should make ourselves content in every situation so that we are always delighted" 32 . We must, therefore, "apply ourselves to winning over our souls to that and educating [our souls] until that becomes an intrinsic habit for us and an acquired disposition" ${ }^{33}$. Thus, the cure of the soul consists in a slow ascent in the acquisition of praiseworthy habits from the lesser and more easily acquired to the harder and more significant, while habituating the soul to patience over things that elude it and consoling it for things lost ${ }^{34}$.

Al-Kindī indicates that our sorrows are the result of possessions. Here we are called upon to bear in mind that "the common possessions that we have are a loan from the Lender, who is the Creator of possessions (great is His praise), [Who] can retrieve his loan whenever he wants and give it to whomever He wants"35. Our passage through this world of destruction is likened to that of "a group traveling by boat to a destination they intend to be their homeland" 36 When the boat drops its anchor so that the passengers may disembark and seek provisions, some do so quickly and return to "the roomiest berths and most comfortable seats

${ }^{30}$ Al-Kindī, On the means of dispelling sorrows, 2, in op. cit., p. 23.

${ }^{31}$ Ibidem.

32 Al-Kindī, On the means of dispelling sorrows, 6, in op. cit., p. 25.

33 Al-Kindī, On the means of dispelling sorrows, 8, in op. cit., p. 25.

${ }^{34}$ See C.E. Butterworth, "Ethical and political philosophy," in P. Adamson, R.C. Taylor, The Cambridge Companion to Arabic Philosophy, Cambridge 2005, p. 270.

35 Al-Kindī, On the means of dispelling sorrows, 16, in op. cit., p. 29.

${ }^{36}$ Al-Kindi, On the means of dispelling sorrows, 21, in op. cit., p. 31. 
without any competitors or rivals preventing that" ${ }^{37}$. Others - who also tend quickly to their needs, but pause to absorb the beautiful scenery and enjoy the different scents together with the songs of the birds, gaze upon the beautiful surrounding sights and enjoy the delightful aromas return to narrower, less comfortable seating. Yet others "eagerly devoted themselves to gathering up those shells and stones and nearby fruits and flowers, without leaving the place where they had met their needs" 38 . They find only cramped, rough and uneven seating and end up regretful and afflicted by sorrow and worry; one of them might even go missing. Finally, others penetrate far inland "forgetting about the boat and the place that they intended to be their homeland" 39 immersed as they are in the surrounding natural beauty and the objects to be collected the purpose of the voyage. Of these, those who hear the ship captain's call and return before it sails, find cramped, uncomfortable seats. Others wander so far away that the captain's call never reaches them and, left behind, they face "deadly vicious dangers and horrific injuries" 40 and perish horribly. Those who return to the ship burdened with objects suffer so, due to the cramped seating, the stench of their decaying possessions, and the effort they consume in caring for them, so that most fall ill and some perish before reaching their berths ${ }^{41}$. Only the first two groups arrive safely at their destination, though those in the second group are somewhat ill at ease due to their narrower seats ${ }^{42}$.

This account emphasizes both the voyage and the conduct of the passengers; it is "like our passage through this world and the simile of the condition of the travelers in this world"43. It provides counsels that should act as permanent models for our souls. These counsels should ultimately act as safeguards against "the damages of sorrow" and help us to "reach the most virtuous homeland of the abode of permanence

37 Ibidem.

38 Al-Kindī, On the means of dispelling sorrows, 23, in op. cit., p. 32.

39 Al-Kindī, On the means of dispelling sorrows, 24, in op. cit., p. 32.

40 Al-Kindī, On the means of dispelling sorrows, 25, in op. cit., p. 32.

${ }^{41}$ See Al-Kindī, On the means of dispelling sorrows, 26 in op. cit., p. 33.

${ }^{42}$ C. Butterworth, op. cit., p. 270.

${ }^{43} \mathrm{Al}$-Kindī, On the means of dispelling sorrows, 27 in op. cit., p. 33. 
and the dwelling place of the righteous" 44 . The story demonstrates that we have nearly complete freedom over the way we conduct ourselves on our voyage. Our use of that freedom determines whether we reach our goal happily or suffer throughout the voyage and perhaps even perish.

\section{b. Abû Bakr al-Râzī}

Al-Râzī, the Persian philosopher-physician (c. 864-925 or 932), wrote an intriguing treatise entitled The Philosopher's Way of Life based on the writings of Galen. In it he encourages the reader to reform his character and to embark upon the study of logic and philosophy. For an Islamic philosopher, al-Rāzì was quite innovative in that he articulated a rather rational normative ethics, based on a consideration of God's basic attributes of intelligence ('aql), justice ('adl) and compassion (rahma). All three are among the ninety-nine most beautiful names of God (asma Allah al-husnā). Given that God is merciful and tries to diminish pain, al-Râzī attacks the ascetic practices of various religions:

Since neither reason nor justice grants people the right to harm others, it follows that neither should they harm themselves. Many examples fall under the general notion of self-harm that reason rejects., like the Hindus who, in seeking to be near God, set fire to themselves and fling themselves on sharp nails, or like the Manis ${ }^{45}$ who castrate themselves to resist the urge for sex, weaken themselves through hunger and thirst, and allow themselves to get filthy by avoiding water, using urine instead. Also falling under this heading to a much lesser degree, are Christians who practice monasticism and withdrawal from the world in cloisters, as well as many Muslims who spend all their time in mosques, give up daily affairs, and limit themselves to a small amount of unpalatable food, and to wearing painful and uncomfortable clothes. All such behavior is just a form of self-oppression and self-harm that does not help one avoid a more preferable pain ${ }^{46}$.

44 Al-Kindi, On the means of dispelling sorrows, 33, in op. cit., p. 35.

45 The Manichaeans.

46 Al-Rāzī, The Philosopher's Way of Life, 16, in Classical Arabic Philosophy: An Anthology of Sources, translated with Introduction, Notes, and Glossary by J. McGinnis \& D.C. Reisman, Indianapolis/Cambridge [MA] 2007, p. 41. 
His portrayal of the philosophic life depends on six principles upon which he bases his whole teaching, but he comments extensively only on two of them. One stresses that "we should not seek out a pleasure the attainment of which requires the perpetration of something that prevents our liberation in the eternal world of the soul or that imposes on us in this world a harm greater and more intense in quantity and quality than the pleasure we chose" 47 . The other emphasizes the way "that our Lord and Master takes a concern in us, watches over us, and has compassion for us"48.

This latter principle should lead to the imperative that "we must not harm any sentient creature whatsoever unless it is absolutely necessary to inflict that harm or by doing so we avert a greater harm" ${ }^{49}$. In his elaboration of this principle, al-Râzì leads the reader to consider the existence of a hierarchical structure within society:

Since people differ in their circumstances - some accustomed to prosperity, some to hardship, and some seeking gratification, of one desire more than another (such as those passionate about women, or wine or power, or any other thing in which people show great diversity) - the pain they experience by restraining their desires varies according to their differing circumstances ${ }^{50}$.

Consequently, "people cannot be burdened in the same manner but rather differently, according to their different circumstances" ${ }^{51}$. Such distinctions pave the way towards the formulation of a morality, something he denotes as the upper and lower limits. He refers to the former "in terms of freely pursuing the enjoyable life," whereas the latter is referred to "in terms of self-denial and self-restraint" ${ }^{2}$. At this point al-Râzì urges that one not go against knowledge, justice and compassion on the one hand, nor come to personal harm or excessive indulgence in pleasure on the other. This leads him to the conclusion that "those born to poor fathers

47 Al-Rāzī, The Philosopher's Way of Life, 11, in op. cit., p. 39.

48 Al-Rāzī, The Philosopher's Way of Life, 13, in op. cit., p. 39.

49 Al-Rāzī, The Philosopher's Way of Life, 13, in op. cit., p. 40.

50 Al-Rāzì, The Philosopher's Way of Life, 17, in op. cit., p. 41.

${ }^{51}$ Ibidem.

${ }^{52}$ Al-Rāzì, The Philosopher's Way of Life, 18, in op. cit., p. 42. 
and raised in straitened circumstances are superior, because self-restraint and self-denial are easier for such people, just as they were easier for Socrates than for Plato" 53 .

All of this is encapsulated in what al-Râzì believes is the essence of the philosophic life: "Philosophy as imitating God (mighty and exalted is He!) to the degree that humans are able" 54 .

\section{THE THEME OF SUFFERING IN THE MYSTICAL TRADITION}

The theme of suffering has played a vital role in the mystical tradition of Islam, especially in its early stages. It is set within the mystic's quest for union with God (ittihād) which requires a process of self-denial to the point of losing oneself in God $\left(f a n \bar{a}^{\prime}\right)$, just as in love poetry where the lover loses oneself in the beloved.

In his Treatise 'Abd al-Karīm b. Hawāzin Qušayrī (d. 1074) analyzes by way of a series of essays some major terms and concepts pertaining to the Sûfî tradition, among which are "the veil" (sitr) and "self-manifestation" (tağallī). He evokes the theme of the awesome brilliance of unmediated divine light. It is incumbent upon humans to seek divine light and to seek the removal of the veils that deprive them of such illumination ${ }^{55}$. But for those Șûfis who have progressed in their path divine light becomes overwhelming in its brilliance; it blinds, stuns, and can even consume whoever seeks it. They are bewildered by such brilliance and find respite in being veiled ${ }^{56}$. By way of example Qušayrī cites an anecdote concerning a young man who is so overwhelmed by the brilliance of the dust from his beloved's footsteps that he becomes fearful of what would happen to him were she to allow him to appear before her:

53 Al-Rāzī, The Philosopher's Way of Life, 18, in op. cit., p. 42.

${ }^{54}$ Al-Rāzī, The Philosopher's Way of Life, 20, in op. cit., p. 42.

${ }_{55}$ See M.A. Sells, Early Islamic Mysticism: Sufi, Qur'an, Miraj, Poetic and Theological Writings, New York/Mahwah 1996, pp. 129-130. Here one might detect a connection between the concept of sitr as portrayed in Șüfĩ Islam and that of maya in Hinduism, especially in the literature of the Upaniṣads. See Śvetáśvatara Upanișad, 4.9-10.

56 This concept is reminiscent of the incident found in Ex. 34:5-8.29-35. 
A dervish appeared among one of the Bedouin tribes. A young man offered him hospitality. While the young man was serving the dervish, he suddenly fell unconscious. The dervish asked about the young man's swoon, and they said: "he has fallen for his paternal cousin. And she was moving about in her tent, the young man caught a glimpse of the dust raised by the train of her gown and fainted". The dervish went to the door of the tent and said: "Your custom is to offer the stranger a certain esteemed position and prerogatives of hospitality. I have come to intercede with you on behalf of the young man. Show your favour for the love he holds for you". She said: "God be praised! You are a man of sound heart. He cannot bear to witness the dust of the train of my gown. How could he possibly bear keeping company with me?"57

This anecdote is in many ways a reflection on a passage from the Qur'ân in which Moses asks God that he might see his face:

And when Moses came on Our appointed time and his Lord spoke to him, he said: "Lord, show me [Yourself] so that I may look at You." He said: "You will not see Me; but look at the mountain. If it stays in its place, you shall see Me." But when his Lord revealed Himself to the mountain, He leveled it to the ground, and Moses fell down unconscious. When he woke up, he said: "Glory be to You, I repent unto You and I am the first of the believers". ${ }^{58}$ (Q. 7:143)

Therefore, as Michael Sells affirms, life lies in self-manifestation (tağallī), and suffering (balä) consists in being veiled. As for the privileged, however, "they are between wander-loss and life because when there is self-manifestation to them, they wander lost $(t \bar{a} \bar{s} \bar{u})$, and when they are veiled, they return to well-being and life" 59 .

${ }^{57}$ Qušayrī, Al-Risāla 'l-Qušayriyya li 'l-Tașawwuf, in Sells, op. cit., p. 130.

${ }^{58}$ Compare this text with the a similar plea made by Moses in the Book of Exodus: Moses said, "I beg you, show me your glory." And he (God) said, "I will make my goodness pass before you, and I will proclaim before you my name 'The LORD', and I will be gracious to whom I will be gracious, and will show mercy on whom I will show mercy. But," he said, "you cannot see my face; for man shall not see me and live". And the LORD said, "Behold, there is a place by me where you shall stand upon the rock; and while my glory passes by I will put you in a cleft of the rock, and I will cover you with my hand until I have passed by; then I will take away my hand, and you shall see my back; but my face shall not be seen. (Ex. 33:18-23).

${ }^{59}$ Sells, op. cit., p. 130. 
Abû 'l-Qāsim al-Ğunayd (d. 910) is perhaps the most famous of the early Sunfīs within Islam. His sayings and writings, specially his treatises on tawhìd (the affirmation of divine unity) focus on the trial or test (balä) that the Suufĩ must undergo to encounter reality, and the overpowering, even violent nature of the manner in which the person is seized, overwhelmed and obliterated by the divine nature. Ğunayd's articulation of the ego-self being lost through union with the divine became a core of Islamic mystical thought. Sells portrays this trial as "the continual struggle against this spiraling circle of ego-self, which ends with the real overwhelming the human, working through and upon the human, subjecting (istawlā 'alā) and making the human subject to the workings of the real within the human" ${ }^{00}$. Gunayd and other early Șûfîs based this concept of mystical union on the famous divine saying: "When my servant draws near to me through obligatory and free devotions .... I become the hearing with which he hears, the seeing with which he sees, the hands with which he touches, the feet with which he walks, and the tongue with which he speaks" ${ }^{1}$. Existence for Gunayd is fundamentally the existence of the real. When human beings give up their self-existence, through the long process of trial, the painful death of the ego-self, then they exist and abide in the existence-of-the-real-for-them. In this sense Gunayd speaks of the real existence as a transitive force, of the real as "ex-isting them," or "founding them," that is, infusing them with the genuine existence of the one reality ${ }^{62}$.

With al-Husayn b. Mansūr al-Hallāğ (d. 922) the theme of suffering for the sake of the beloved culminates in abandonment, madness and despair. This situation is vividly portrayed in Chapter 6 of his work Kitāb al-Tầwāsin, where he surprisingly (and scandalously) describes Iblīs (a corruption of the Greek term diabolos) as a tragic lover. The common interpretation of the Qurânic story is that Iblīs refused out of pride to bow down before a human being made of an inferior substance (mud or clay - Iblīs being made of fire according to tradition) and inferior in stature:

\footnotetext{
${ }^{60}$ Sells, op. cit., p. 258.

${ }^{61}$ From Buhārī, Sahīh 81:38.

${ }^{62}$ Sells, op. cit., p. 257.
} 
Your Lord said to the angels, 'I will create a man from clay. When I have shaped him and breathed from My Spirit into him, bow down before him' The angels all bowed down together, but not Iblis, who was too proud. He became a rebel. God said, 'Iblis, what prevents you from bowing down to the man I have made with My own hands? Are you too high and mighty?' Iblis said, 'I am better than him: You made me from fire, and him from clay'. 'Get out of here! You are rejected. My rejection will follow you till the Day of Judgement!' But Iblis said, 'My Lord, grant me respite until the Day when they are raised from the dead', so He said, 'You have respite till the Appointed day'. Iblis said, 'I swear by Your might! I will tempt all but Your chosen servants'. (Q. 38:71-82) ${ }^{63}$

As Sells rightly points out, "al-Hallāğ’s retelling of the story, Iblīs's pride and disobedience are clearly present, but the issue is woven deeply into the intricacies of love-madness, monotheistic loyalty, and theological meditations on divine predetermination and free will"64. Iblis's monotheistic claim - that he refused to bow before an other-than-God even at the risk of eternal rejection and torment - is combined with the lyrical language of the character of a love-struck youth from Arab literature, taken from the epic tale of Layla and Mağnūn, in which the lover's loyalty is so total that there is no path for him to any "other than" the beloved ${ }^{65}$. The tragic paradox is there for all to behold: In his total loyalty, the lover is willing to risk everything - including separation from the beloved before being disloyal ${ }^{66}$. When accused of pride, Iblīs acknowledges it, but justifies his pride by pointing to the intimacy he has shared with the deity:

9. He (i.e., Iblīs) was told: "Bow down!” He said, “[to] no other!" He was asked, "Even if you receive my curse?" He said, "It does not matter. I have no way to an other-than-you. I am an abject lover".

${ }^{63}$ See also Q. 2:34; 7:11-13. Cf. the parallel narrative in the Old Testament apocryphal work entitled Vita Adae et Evae, chs. xii:1-xvi:4 wherein Adam encounters Satan after his and his wife's expulsion from Paradise and Satan reveals to him the reason why he had ensnared him.

${ }^{64}$ See Sells, op. cit., p. 269.

${ }^{65}$ See Sells, op. cit., p. 271. The love story of Layla and Mağnūn is supposedly based on a true story of the Arab-Bedouin poet from the north Arabian peninsula, Qays b. al-Mulawwah, who lived in the $7^{\text {th }}$ century during the period of the Umayyad dynasty.

${ }^{66}$ See Sells, op. cit., p. 273. 
10. My disavowal in you is taqdīs (affirmation of transcendence)

My reason in you, befuddlement.

Who is Adam other than you?

To distinguish them, who is Iblīs?

[and the one in between is Iblīs]

11. He (i.e., God) said: He disdained and grew proud, turned away and backed around, and what he insisted upon, set down.

He said, "You have grown proud". He replied, "A moment with you would be enough to justify my pride and lording-it-over (tağabbur). So how much more am I justified when I have passed the ages with you. (7:11) 'I am better than him' because of my priority in service. There is not in the two creations anyone more knowing of you than I. I have a will in you and you have a will in me. Your will in me is prior and my will in you is prior. If I bow before an other-than-you or do not bow, I must return to my origin, for (7:11) 'you have created me from fire.' Fire returns to fire. To you belongs the determination and the choice".

12. There can be no distance from me

distancing you from me

When I have achieved certainty nearness and distance are one.

Even if I am abandoned, abandonment will be my companion.

How can it be abandonment while love is one?

To you, praise in success, in the pure absolute

For a servant of true heart who will bow to no other than you ${ }^{67}$.

Al-Hallāğ himself suffered the cruelest of tortures during his final imprisonment and execution. His hands and feet were severed, and he was placed on the cross (sali $b$ ) or, more probably, on the gallows, and finally decapitated; his body was burned and the ashes were thrown into the Tigris in order to erase all remembrance of him. This was the death for which his entire life had been a preparation. He had often urged the people of Baghdad to kill him so that he might be united with God and they might be recompensed for defending their simple and sincere faith. One of his most touching hymns begins with the words: "Kill me, o my

${ }^{67}$ Al-Hallāăg, Kitāb al-Ṭāwāsīn, in Sells, op. cit., p. $274 \mathrm{f}$. 
trustworthy friends, for in my being killed is my life". This phrase has been repeated by mystics throughout the ages as a basis for their meditations ${ }^{68}$.

\section{CONCLUSION}

Human suffering in all its manifestations has always accompanied human existence. In this context the role of religion is not that of eliminating it, but in looking at it from the perspective of God's relationship to humanity. In the eyes of the devout Muslim suffering is an occasion for submission to the divine will and for the affirmation that God is Lord of all creation. Before God, the Giver of all things, everything pales into insignificance. The Qur'ân lends authority to this perception with the words: "Everyone on earth perishes; all that remains is the Face of your Lord, full of majesty, bestowing honour" ${ }^{\text {. }}$.

Abstact. The human experience of suffering can be considered in its various manifestations: physical, psychological, moral and spiritual. Sometimes these are interconnected, and it is difficult to distinguish among them. This paper is intended as an overview of the concept and experience of suffering in the Islamic tradition as portrayed in the context of the Qurân and of the life of Muhammad, its exaltation in the cause of religion within the Šisi community, as well as the development of its understanding in theological, philosophical and mystical circles.

Keywords: Islam; suffering; Qur’an; Muhammad; Šììi.

Streszczenie. Cierpienie ludzkie we wszystkich swych formach od zawsze towarzyszyło człowiekowi. Celem niniejszego artykułu jest przedstawienie ogólnego zarysu problemu i doświadczenia cierpienia w tradycji islamu, tj.: w Koranie, życiu Mahometa, teologii szyickiej oraz w świetle rozwoju jego rozumienia w teologicznych, filozoficznych, jak i mistycznych kręgach.

Słowa kluczowe: islam; cierpienie; Koran; Mahomet; szyici.

${ }^{68}$ A.M. Schimmel, Mystical Dimensions of Islam, Chapel Hill 1975, p. 69.

${ }^{69}$ Q. 55:26-27. 